\title{
Sustainable Facilities Management: Interviews with FM practitioners for Malaysian universities
}

\author{
Mohamad Sufian Hasim, Ahmad Sharim Abdullah, \\ Abdul Rauf Abdul Rasam, Hafiszah Ismail
}

Faculty of Architecture, Planning and Surveying, Universiti Teknologi MARA, Malaysia

moham315@uitm.edu.my; sharim@uitm.edu.my; rauf@uitm.edu.my; hafiszah@uitm.edu.my

\begin{abstract}
Sustainability in Facilities Management (FM) is a new approach in managing buildings and may be influenced by practitioners involved within an organisation. Sustainability inthe organisation has a significant impact on organisational success in increasing the firm's profitability,reducing cost and enhancingsafety and health. This paper aims to evaluate the level of sustainability implementation in the university organisations with the objectives to measure an understanding concerning sustainable FM among practitioners, and to determine the sustainability dimension which mostly considered. Sixteen interviews were conducted, and the results found that the majority of participants were not familiar to the sustainability concept and the environmental dimension was higher priorities in FM implementation.
\end{abstract}

Keywords: Sustainable Facilities Management; Malaysian Universities; Sustainable Organisation; Interview

eISSN 2398-4295 (02020 The Authors. Published for AMER ABRA cE-Bs by e-International Publishing House, Ltd., UK. This is an open access article under the CC BY-NC-ND license (http://creativecommons.org/licenses/bync-nd/4.0/). Peer-review under responsibility of AMER (Association of Malaysian Environment-Behaviour Researchers), ABRA (Association of Behavioural Researchers on Asians) and $c E-B s$ (Centre for EnvironmentBehaviour Studies), Faculty of Architecture, Planning \& Surveying, Universiti Teknologi MARA, Malaysia.8pt Italic DOI: http://dx.doi.org/10.21834/ajbes.v5i18.188 


\subsection{Introduction}

The motivation for this study arises from a keen interest in making buildings more sustainable. The lifecycle of buildings has a significant effect on the natural environment such as land degradation, deforestation, waste generation and greenhouse gas (GHG) emissions which are associated with climate change(Intergovernmental Panel on Climate Change, 2007; Metz, Davidson, Bosch, Dave, \& Meyer, 2007). With current development trends, it is predicted that in the long term, these consequences will be more severe (Environmental Protection Agency, 2013; United Nations Environment Programme, 2009). Therefore with a new approach to constructing and managing buildings that includes sustainability principles, the research will contribute to achieving sustainability goals.

Sustainability adopted into practice are essential for organisations as they have a massive influence on organisational success. Sustainability at the organisational level refers to enhancing the firm's profitability, adopting and pursuing ethical business practices, creating sustainable jobs, building value for all stakeholders and, at the same time, meeting environmental and social needs (Porter, 2008; Székely \& Knirsch, 2005). Generally, organisations are adopting the sustainability principle into practice when they undertake initiatives such as using sustainable, green or socially-responsible materials. Thus, all parties involved in constructing and managing buildings, especially organisationsurged to develop and operate buildings in a sustainable way in minimisingthe adverse effects on the natural environment.In the context of a university institution, practitioners or senior management in the FM department can influence organisational response and change. In holding a key position, the manager's knowledge and understanding are essential for the organisation as they could influence the commitment to adopting sustainability practices.

This research aims to evaluatethe implementation of sustainability in FM practices for a university organisation. These institutions are in a unique position to influence the attitudes of the community, and the findings can be used as a lesson learned for other organisationin formulating strategies towards sustainability.

\subsection{Literature Review}

The FM profession is growing and is concerned with managing assets and facilities in the operations and maintenance phase that involves the management of energy, water and waste in alignment with related policies and guidelines (Lavy, 2008; Lee \& Kang, 2013).FM has significant roles in global economic development. For example, in studies conducted in 2009 concerning FM contribution, it was reported that in the UK market, the value of the FM sector was nearly £117 billion and was estimated to be around $€ 1000$ billion in the European Union (EU) nations (Wiggins, 2010). In Australia, FM is one of the fastest-growing industries and key business sectors with an estimated annual turnover of $A \$ 60$ billion, contributing approximately $4 \%$ of GDP on the annual national investment and involving more than 400,000 workers (fmedge, 2012). Thus, this industry has a significant impact on economic development.Figure 1 shows the three elements of FM. 


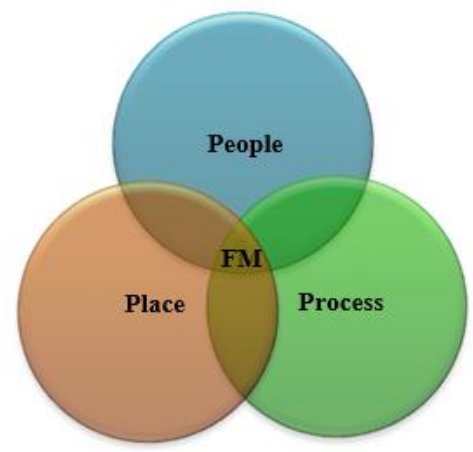

Figure. 1: The FM triangle

(Source: Adopted from Finch and Zhang (2013)

The critical task of practitioners involved (i.e., FM managers) is how to effectively manage these three elements to support the core function of the organisation (Ogbeifun, 2011). Thus, the integration of these three elements is vital for organisational performance. Indeed, FM is one of the crucial aspects of the built environment, and many organisations have now started to realize the strategic role of FM in providing benefits from the investment in assets and facilities (C. Pathirage et al., 2008).

\subsection{Facilities management roles and functions}

FM roles are critical within organisations and are regarded as a high-level management activity which relates to strategic planning and decision-making processes (Langston \& Lauge-Kristensen, 2012). It has a significant influence on organisational achievement as it affects the efficiency of organisational asset strategies that are responsible for ensuring that services are delivered, improving the productivity of building occupants as well as improving the financial returns for organisations (Moller \& McCartney, 2007). Furthermore, FM roles can be considered as the 'housing' in which a wide range of functions such as project management, maintenance management and space management may be brought together for the benefit of the organisation and its employees as a whole (Amaratunga, 2001; Reineck, Poltermann, May, \& Pelzeter, 2012).

Typically FM can be divided into two areas of concern, namely soft and hard roles (Probst-Wallace n.d). Generally, the function of soft FM roles involves the management of support services with activities concerned such as cleaning, waste disposal and security. In contrast, hard FM roles are more related to the management and maintenance of the property, which comprises infrastructure facilities such as management of energy, water and minor project management. The hard FM roles might be considered as a traditional property management function.According to Koukiasa (2011), sustainable practice in FM is the process which facilitates the organisation's ability to become more sustainable. It concurrently enhances the organisation's ability to achieve sustainability by optimizing environmental, financial and social dimensions. 


\subsection{Sustainability practices in facilities management}

Sustainability is not a new concept (Warren-Myers, 2013) and has widely influenced global business practice (Koukiasa, 2011). The advantages of adopting sustainability principles in FM is growing (Nielsen, Jensen, \& Jensen, 2012; Sarpin \& Yang, 2012) and the benefits of sustainability adopted are well established (Nielsen, Møller, Jäschke, \& Alexander, 2012).Generally, the sustainability agenda is commonly connected with three dimensions aiming to optimize environmental protection, economic viability and social progress (Hitchcock \& Willard, 2006; Petrini \& Pozzebon, 2010). Indeed, organisations can only be considered to be moving towards sustainability if all three dimensions are adopted into practices (Boyle, 2003). Figure 2 illustrates these three dimensions.

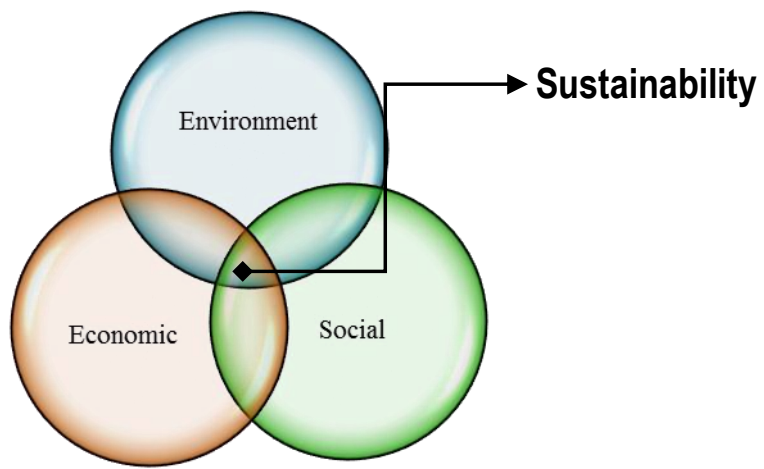

Figure. 2: Dimensions of sustainability

(Source: Adopted and adapted from Beheiry, Chong \& Haas 2006; Khalfan 2002; Shelbourn et al. 2006)

The connection of these three dimensions can be seen in such a way that, for example, if an environmental dimension were adversely affected, it would minimize the critical resources that were needed to advance the economy. If the economy were damaged, unemployment would be high, thus creating many social problems and leading to an unstable community. A volatile community would be too focused on the issues that they faced and would not be concerned about environmental degradation (Hitchcock \& Willard, 2006) and, consequently, would not be bothered about sustainability. Undeniably, all three dimensions need to be effectively integrated to achieve long-term sustainability goals (Robinson,(2004).

In the context of sustainable FM, this advanced practice would provide additional benefits such as reducing the consumption of resources (i.e., energy), having better building design, minimising greenhouse gas emissions, expanding the value of the investment, decreasing operating and maintenance (O\&M) costs, increasing health and safetyand increasing the comfort of occupants (Hodges, 2005; Lee \& Kang, 2013; Williams \& Sutrisna, 2010).For example, in a study on a sustainable initiatives renovation project in Southern California by the United States Green Building Council (2003), 59\% reductionof energy, 
$47 \%$ decrease in employee absenteeism and 5\% increase in employees' productivity among positive outcomes recognized.

Sustainability in FM practiceis not only essential for the management of new assets, but, at the same time, they are crucial for managing existing assets. As the amount of existing buildings is substantial (Elle, Hoffman, Nielsen, \& Jensen, 2005), sustainability practices for such buildings are thus vital as they can provide a positive impact in the transformation towards achieving a sustainable society (Nielsen, Jensen, et al., 2012). The market of existing buildings is 16 times larger than that of new construction, and thus it has a crucial impact on climate change (Mayton (2007). Moreover, sustainability practices for existing building stock are essential because this involves the operation and maintenance (O\&M) stage which is the most extended phase in the asset life cycle dealing with both embodied (used for manufacture) and operational energy (used for operation). Thus, sustainability adoption in FM for existing assets would provide better results in achieving a sustainable goal.

The above discussion indicates that a sustainable FM approach is needed to support the goal of sustainability. There is no doubt that sustainable practice in FM will benefit an organisation.

\subsection{0rganisational commitment to sustainability}

Sustainable practices are essential for organisations as they have a massive influence on organisational success. Sustainability at the organisational level refers to enhancing the firm's profitability, adopting and pursuing ethical business practices, creating sustainable jobs, building value for all stakeholders andmeeting environmental and social needs (Porter, 2008; Székely \& Knirsch, 2005). This approach makes good business sense because it increases the efficiency, effectiveness and accountability of the business operation (Opoku \& Fortune, 2011).

However, to be a successful organisation, sustainability principles must invadeinto all aspects of the organisation (Hitchcock \& Willard, 2006) and a piecemeal approach. Therefore, organisations must embed the sustainability agenda within their organisational structure and governance, such as by establishing a vision and mission policy incorporating sustainability.

Globally, there is a growing trend among organisations in promoting sustainability as a critical business strategy due to a high level of awareness about the impacts of their operations on society and the environment (Bertels, Papania, \& Papania, 2010; Petrini \& Pozzebon, 2010; Vanegas, 2003). In2002 surveyed for the US companies by PricewaterhouseCoopers, revealed that $75 \%$ of companies were adopting some sustainability practices, $73 \%$ planned to issue a sustainability report and $89 \%$ expected sustainability to be more critical after five years (Hitchcock \& Willard, 2006).Moreover, in the 2010 UN Global Compact-Accenture CEO research, more than 90\% of CEOs approved that the sustainability agenda is vital for their future organisational achievements.

Organisational performance and commitment towards sustainability have a significant relationship with the drivers, whether from internal or external sources. According to Ahn, 
Pearce, Wang, and Wang (2013), due to the economic and social benefits, many agencies (i.e., government) have been motivated to adopt more sustainability principles in the built environment (e.g. sustainable design and construction practice).Furthermore, corporations with robust health, welfare and environmental policies are easily moved forwards and progress well towards full sustainability practices (Dunphy, Griffiths, \& Benn, 2003). There are various benefits for organisations that have adopted sustainability in their practices as follows:

1) Minimisation of operating costs and being ahead of one's competitors with sustainability adoption, providing greater prominence for the organisation (Hitchcock \& Willard, 2006). For example, Scandic Hotels in Sweden was losing market share until they adopted sustainability as a focus which now provides an informative narrative for potential guests.

2) Improvement of organisational goodwill as sustainability adoption can position the organisation as pioneering an exciting trend (Hitchcock \& Willard, 2006). For example, Gerding\&Edlen, a development company, has received national recognition in trade journals and on a public broadcasting TV show through their sustainability initiatives.

3) Provision of higher efficiency in terms of materials and energy consumption, increase in transparent and ethical practices, creation of a higher awareness of the needs of current century knowledge workers, respect for local communities, reduction of waste throughout the entire life cycle of the asset and being alert about the need to minimize unnecessary risks (Székely \& Knirsch, 2005).

However, this current study is more concerned with determining the efforts of university organisationstowards sustainability.

\subsection{University commitment towards sustainability}

There are various reasons why university organisations are significant concerning sustainability issues. According to Amaratunga and Baldry (2000), sustainability practices are vital to universities due to various challenges, for example:

a) Comparatively, universities have an extensivechoiceof buildings which need further diverse operational tasks than those of other asset owners or organisations;

b) Universities are trying to improve their efficiency while facing the challenges of growing operating costs and increasing user expectations;

c) The massive expansion has forced universities to achieve more economical use of their facilities.

From the FM perspective, to be a successfulorganisation, the university is mandatory to adopt sustainability into practices. Since the university holds a full range of assets including infrastructure (e.g. drainage system, roads and telecommunication systems) and buildings of various ages, functions and types such as offices, commercial and leisure facilities (Amaratunga \& Baldry, 2000). All of the issues identified are pushing universities to change, and their FM department needs to understand this change and build the capacity 
for change to help universities succeed in today's competitive environment. Therefore, progressive FM requires university organisations to adopt sustainability into practice to combat these circumstances vigorously.

\subsection{Methodology}

This study engaged face-to-face semi-structured interviews to gather in-depth information from the head of a department in the facilities management office and senior practitioners. These target participants were directly dealt with operational activities, such as the managerial positions in the planning and design department, engineering department, procurement department, building department, property department or maintenance department. FM practitioners in the context of this study refer to the specific participants' professions such as facilities managers, engineers, project managers, architects, quantity surveyors, planners and sustainability managers. In achieving the study objectives, five participants from each university were invited with a total of 16 participation. According to Guest, Bunce and Johnson (2006), a range between six and 12 participants was sufficientfor interviews in developing substantial themes and achieving research objectives. Figure 3 outlines the flow chart for the interview process.

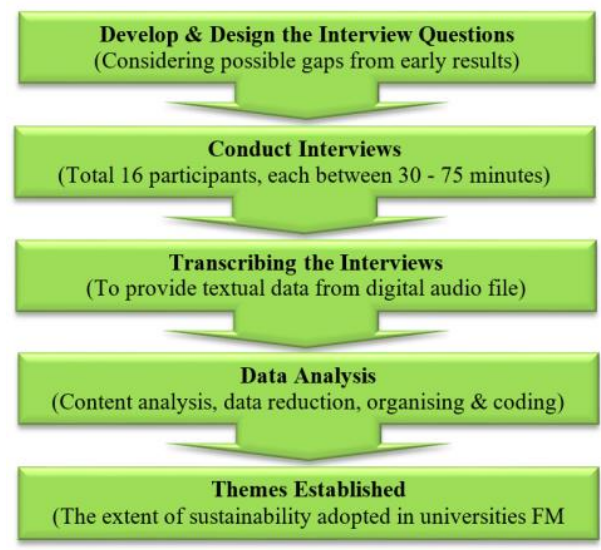

Figure. 3: Flow chart for the interview process

Four universities were chosen representing different groupings of Malaysian universities,'Research University' and 'Comprehensive University'. Table 1 shows the list of universities involved and the number of participants.

Table 1: List of universities

\begin{tabular}{|c|c|c|}
\hline University & $\begin{array}{c}\text { Nos. of } \\
\text { Participants }\end{array}$ & Group \\
\hline (A) & 4 & Comprehensive University (CU) \\
\hline
\end{tabular}




\begin{tabular}{|l|l|l|}
\hline$(B)$ & 4 & Research University (RU) \\
\hline$(C)$ & 5 & Research University (RU) \\
\hline$(D)$ & 3 & Research University (RU) \\
\hline
\end{tabular}

A well-structured series of questions was required for this study, and this would provide the whole picture of all of the issues that needed severe thought in addressing the research questions and objectives (Yin, 1994).The specific themes of the questions related to the objective of the study were 'knowledge and understanding concerning sustainability concept and FM practices' and 'key sustainabilityinitiatives undertaken'. Participants' opinions were summarised and evaluated to assess how these opinions varied based on their understanding. The themes were presented in the form of tables to get a clear picture. Where appropriate, the results were presented by incorporating a ranking of the themes. This was derived from the total number of statements across all of the interviews and not by the number of participants. The total number of statements may, therefore, be higher than the number of participants. This ranking could be assumed from the priorities that participants have given to the themes (Marlow, 2008). Besides, typical and relevant participants' quotations were included to portray expert opinions and to assist in making conclusions.

There are limitations in this study that are yet to be discovered. As this study engaged an interview as a method for collecting data, the researcher, as an objective observer, did not conduct any observation on body language, gestures or other associated signals during the interview session. The results only based on the perception of 16 FM practitioners in four selected universities. Furthermore,no photos were taken during the processes, and the interviews were in a mixture of English and the Malay language.

\subsection{Results}

This section portrays two significant sets of results. Firstly, Section 4.1 presents the participants' knowledge and their understanding concerning sustainability. Secondly, Section 4.2 reports on the extent of sustainability adoption in three different dimensions within their FM practices.Details of the results are described in the following.

\subsection{Analysis of knowledge and understanding of sustainability}

Participants were interviewed to ascertain their knowledge and understanding about the sustainability agenda in general, and sustainability within university FM practices in particular. The manager's knowledge and understanding were necessary for the organisation as they could influence the commitment to adopting sustainability into practice. The literature has supported the view that the understanding of the subject matter would create value that would accelerate the integration of sustainability within the organisation.

\section{(a) Sustainability knowledge in general}


Under 'knowledge and understanding', this study acknowledged several relevant themes that were expressed by participants based on their perception of the sustainability concept in general. Table 2 provides a list of the themes ranked following percentage distribution.

Table 2: Knowledge of sustainability in general

\begin{tabular}{|c|l|c|}
\hline Ranked & \multicolumn{1}{|c|}{ Theme } & $\begin{array}{c}\text { Percentage } \\
(\%)\end{array}$ \\
\hline 1. & Planning for the long term & 25 \\
\hline 2. & Minimize impact on the environment & 19 \\
\hline 3. & Greening approach & 19 \\
\hline 4. & Cost minimization/reduction & 12.5 \\
\hline 5. & The implementation that fulfils needs & 12.5 \\
\hline \multicolumn{2}{|c|}{ TOTAL } & 100 \\
\hline
\end{tabular}

Overall, the results suggested that most statements from the participants specified that sustainability was about planning for the long-term benefit $(25 \%)$ and minimising impact on the environment (19\%). For example, they stated that:

'... this means managing the assets that can be used for a long period of time ...' (participant \#1).

$\therefore$ is the maintenance planning and development that we do ... It should have an impact on future generations. So we make sure that what we make can be used for at least 20 years ... must meet the requirements in the near future, at least 10 to 20 years ...' (participant \#2).

$\therefore$... related activities that ensure the development and building do not just meet needs for 5 to 10 years but for the long term ... and the design could stand for 100 years ...' (participant \#3).

"... I believe sustainability is about the environment ... I would like to see more green done to my campus ..." (participant \#4).

The majority of participants reported that they were not really familiar with, nor did they understand this concept that was relatively new to them. Therefore, their opinions about the subject matter were still unclear. The following comments are from statements made by participants:

'Sustainability? I have heard about it, but I do not quite understand the details ... but what I understand, probably it is about energy saving' (participant \#5).

'I have heard about sustainability, but I am not familiar with it.' (participant \#6).

\section{(b) Sustainability knowledge concerning FM practices}

Eight(8) themes were established concerning the level of understanding of sustainability in FMpractices. Table 3 provides a list of themes in ranked order showing the percentage distribution.

Table 3: Knowledge of sustainability in FM

\begin{tabular}{|c|l|c|}
\hline Ranked & \multicolumn{1}{|c|}{ Theme } & $\begin{array}{c}\text { Percentage } \\
(\%)\end{array}$ \\
\hline 1. & Green building (i.e. certification) & 26 \\
\hline 2. & Water conservation/recycling/reuse & 20 \\
\hline 3. & Design consideration (i.e. less embodied energy material) & 13 \\
\hline 4. & Cost minimization/reduction & 13 \\
\hline 5. & Energy conservation/efficiency & 7 \\
\hline 6. & Recycling of materials & 7 \\
\hline
\end{tabular}




\begin{tabular}{|c|l|c|}
\hline 7. & Minimize maintenance and maximize efficiency & 7 \\
\hline 8. & Prolong life of the asset & 7 \\
\hline TOTAL & 100 \\
\hline
\end{tabular}

As expected, the study showed similar results for participants in term of their level of knowledge. Most statements from participants suggested that sustainability practices in FM were about 'promoting the green building certification' (26\%), 'water conservation' $(20 \%)$ and 'design considerations' (13\%). One participant stated that:

'... it is about the selection of materials that we want to use, towards achieving the Green Building Index (GBI) rating ... using recycled water, using wastewater from sewer systems or black water ... in terms of lighting design, taking into account the orientation of the building ... also a consideration of good ventilation ...' (participant \#7).

\subsection{Analysis of the extent of sustainability adoption in FM practices}

This Section 4.2 reports on the extent of sustainability adoption in three different dimensions within FM practices. Generally, the results indicated that, among the three sustainability dimensions, the environmental performance was the most widely focused in their FM practices.Details of each dimension are described in the following.

\section{(a) Environmental sustainability dimension}

The study identified eight (8) relevant themes for the environmental initiatives undertaken which were established based on participants' descriptions. Table 4 provides the list of environmental initiatives ranked showing the number of statements and percentage distribution.

Table 4: Environmental sustainability

\begin{tabular}{|c|c|c|c|}
\hline Ranked & Theme & Description of Initiatives & $\begin{array}{c}\text { Percentage } \\
(\%)\end{array}$ \\
\hline 1. & Energy & $\begin{array}{l}\text { Energy efficiency - (zoning, installing efficient } \\
\text { technology (i.e. LED lights, sensors)) }\end{array}$ & 30 \\
\hline 2. & Waste & Reduction/recycling & 27 \\
\hline 3. & Water & $\begin{array}{lll}\begin{array}{l}\text { Conservation/reduction/recycling/reuse } \\
\text { irrigation, rainwater harvesting) }\end{array} & \text { (i.e. } & \text { for } \\
\end{array}$ & 22 \\
\hline 4. & $\begin{array}{l}\text { Green } \\
\text { building }\end{array}$ & $\begin{array}{l}\text { Implementing the Green Building Index (GBI) rating } \\
\text { system (i.e. Platinum) }\end{array}$ & 5 \\
\hline 5. & Biodiversity & Preservation - green landscaping, replanting trees & 5 \\
\hline 6. & Champion & $\begin{array}{l}\text { Appointing/forming a special position (Energy } \\
\text { Manager, Committee) }\end{array}$ & 5 \\
\hline 7. & $\begin{array}{l}\text { Environmental } \\
\text { policy }\end{array}$ & $\begin{array}{l}\text { In new projects or buildings - embedding sustainable } \\
\text { policy/plan/guidelines }\end{array} \begin{array}{lll}\text { (i.e. } & \text { environmental } \\
\text { management plan) } & & \end{array}$ & 3 \\
\hline 8. & $\begin{array}{l}\text { Building } \\
\text { Management } \\
\text { System }\end{array}$ & Developing a system for control and monitoring & 3 \\
\hline \multicolumn{3}{|r|}{ TOTAL } & 100 \\
\hline
\end{tabular}


Universities in Malaysia were identified as having higher priorities for both energy efficiency (30\%) and waste reduction (27\%). Moreover, water conservation (22\%) initiatives were among crucial initiatives that had priority, for example, the introduction of rainwater harvesting for new building projects. Participants mentioned that:
'... one significant initiative that we have undertaken was a rainwater harvesting system for new buildings. At the moment, we have four as a pilot project ... and then we recycle the water ... we collect and reuse it directly or filtered ...' (participant \#10).
"... yes, we have a target to be a zero-waste campus by 2015 , and now maybe we recycle only $20 \%$ with $80 \%$ still going to landfill ... here we also have a water harvesting system for rainwater. We put in a tank to harvest the water and then put it back for toilet use ... that system is only for the new buildings ..." (participant \#11).

\section{(b) Economic sustainabilitydimension}

In terms of economic sustainability, the study revealed much more limited information from university organisation. The study revealed the economic initiatives only were via cost reduction approaches. This can be seen in the standardization of design requirements using the same materials, systems and equipment, and the use of facing bricks (bricks intended to be visible) to reduce the painting costs. Interestingly, universities had an initiative which involved engaging local contractors and utilising local products for their projects. This was mentioned by one participant who stated that:

'... so we are looking for local contractors ... in the tender invitation notice, we put that our advertisement is open to local registered contractors [aboriginal] only ...' (participant \#5, MY).

\section{(c) Social sustainability dimension}

Overall, five (5) social initiative themes emerged which were relevant to social sustainability. Table 5 provides a list of social initiatives undertaken in Malaysian universities ranked by the number of statements and percentage distribution.

Table 5: Social sustainability

\begin{tabular}{|c|l|l|c|}
\hline Ranked & \multicolumn{1}{|c|}{ Theme } & \multicolumn{1}{|c|}{ Description of Initiatives } & $\begin{array}{c}\text { Percentage } \\
(\%)\end{array}$ \\
\hline 1. & $\begin{array}{l}\text { Participation and } \\
\text { involvement }\end{array}$ & $\begin{array}{l}\text { Consultation/participation from various groups } \\
\text { (i.e. campus community, local community) }\end{array}$ & 50 \\
\hline 2. & $\begin{array}{l}\text { Increasing } \\
\text { human capital }\end{array}$ & $\begin{array}{l}\text { Knowledge enhancement - education, training, } \\
\text { further studies, site experiences, establishing } \\
\text { websites, publicity campaigns (i.e. posters on } \\
\text { various themes) }\end{array}$ & 22 \\
\hline 3. & $\begin{array}{l}\text { Health and } \\
\text { safety }\end{array}$ & $\begin{array}{l}\text { Occupants' health and safety - of people, } \\
\text { productivity benefit, safety monitoring }\end{array}$ & 17 \\
\hline 4. & Public access & $\begin{array}{l}\text { Access to facilities - changing operational nature } \\
\text { of building for more flexibility, disabled access } \\
\text { path provided }\end{array}$ & 5.5 \\
\hline 5. & $\begin{array}{l}\text { Occupiers' } \\
\text { satisfaction }\end{array}$ & Surveys on customer satisfaction & 5.5 \\
\hline \multicolumn{2}{|c|}{ TOTAL } & 100 \\
\hline
\end{tabular}


Specifically, the key initiatives undertaken by FM departments for social sustainability were participation and involvement of the community (50\%), increasing human capital $(22 \%)$ and occupants' health and safety (17\%). Participants stated that:
'... before we implement any project, we organise a briefing ... We invite relevant faculties and students. We ask them their view and requirements ... For example, I have implemented one project called 'eco-terrace' which was a commercial building for students who are interested in small business ... So, we have collaboration with the Faculty of Architecture to give their input to achieve the aim of the project ... We discussed with them and developed an idea ...' (participant $\# 10)$.
... for social initiatives, we have a committee on human well-being. Its function is to study the level of satisfaction among the campus community who live on the university campus. Currently, they have started their research on this matter ...' (participant \#12).
'... in terms of safety, we already have some guidelines which are from OSHA (Occupational Safety and Health Act) and the Occupational Health Unit ... to monitor safety and health-related issues ... we also have ... a campaign to enhance awareness and education about energy and water savings ...' (participant \#2).

\subsection{Discussion}

Interviews revealed that the majority of FM practitioners in university organisations were not familiar with the actual concept of sustainability. The practitioners were unable to explain the definition explicitly due to their unfamiliarity with the concept. The practitioners were little exposed to the sustainability agenda and had a basic understanding of the subject matters.However, comparatively, the practitioners have more excellent knowledge and understanding about environmental than economic and social dimension. FM practitioners could elaborate on environmental sustainability, which indicated their higher exposure to, and understanding of it.

Concerning the extend of sustainability adoption in FM practices, the environmental sustainability dimension was emphasised in practice by universities' FM in Malaysia. This is predictable since most studies so far lead to similar conclusions. Although findings generally show that economics is the central theme for FM and particularly in reducing costs to maintain sustainability, the majority of studies consistently found that environmental sustainability plays a significant role in FM implementation (Beheiry, Chong, \& Haas, 2006; Nielsen \& Galamba, 2010; Wright \& Wilton, 2012). This study suggests that the focus on environmental sustainability has a significant relationship with the level of understanding among FM practitioners. This is supported by astudy on sustainable FM among practitioners shows that familiarisation with concepts or subject matter increases the performance in that area, that is, sustainability practices (Adewunmi, Omirin, \& Koleoso, 2012).These findings are also consistent with the argument that knowledge and understanding of the subject matter facilitate changes that can accelerate the adoption of sustainability practices within the organisation (Bakhtiar, Li, \& Misnan, 2008; Du Plessis, 2007; Hecht, 1999; Petrini \& Pozzebon, 2010).

Although limited information was revealed from interviews concerning economic sustainability, it seems that certain aspects were mentioned. There were efforts to reduce asset cost as part of universities' FM initiatives and to engage local contractors and use 
local products in the projects. However, this study assumed that the limited information on this aspect from the interviews might be due to the unfamiliarity of the FM practitioners with the concept of economic sustainability compared to environmental and social sustainability. Therefore, this research has demonstrated that a high level of knowledge and understanding among FM practitioners would influence the successful adoption of sustainable FM practice in universities.

\subsection{Conclusion}

This research can be considered as part of a more significant organisational effort in managing sustainability, focusing on universities. University organisations showed a commitment with various initiatives undertaken towards sustainable FM practices. This study has identified that the environmental sustainability dimension were mostly implemented than two other dimensions. Theinitiatives in SFM undertaken by universities potentially could be adopted and applied across a broader range of organisations such as government departments (hospitals, schools), the private sector and other building stock (asset owners) which will contribute to achieving sustainability goal.Nevertheless, a single organisation such as a university on its own cannot be responsible for making all of society sustainable; however, commitments and participation are needed from all organisations, both private and public to adopt sustainability in their organisational practice.

As for a recommendation, strategies for enhancing the practitioners or manager's knowledge and understanding are highly significant for the organisation. With comprehensive knowledge and understanding concerning the sustainability agenda, the adoption of sustainability can be quickly and may contribute to higher sustainable FM performance. Indeed, as a critical position in the FM department, these practitionerspotentially influence the effort and commitment to embedding sustainability within organisational governance.

\section{Acknowledgement}

The authors gratefully acknowledge the support grant in producing this paper under the GeranPenyelidikan LESTARI (Project Code: 600-IRMI/MyRA 5/3/LESTARI (056/2017) funded by UniversitiTeknologi MARA, Malaysia. The authors would like to extend the appreciation to Associate Professor Dr Stephen Pullen and DrAlpanaSivam from University of South Australia (UniSA), Adelaide, Australia, for their advice and guidance for this research.

\section{References}

Adewunmi, Y. A., Omirin, M., \& Koleoso, H. A. (2012). Developing a sustainable approach to FM Practice in Nigeria. Facilities, 30(9/10), 1-1. 
Ahn, Y. H., Pearce, A. R., Wang, Y., \& Wang, G. (2013). Drivers and barriers of sustainable design and construction: The perception of green building experience. International Journal of Sustainable Building Technology and Urban Development, 4(1), 35-45.

Alexander, K. (1996). Facilities management: theory and practice: Taylor \& Francis.

Amaratunga, D. (2001). Theory building in facilities management performance measurement: application of some core performance measurement and management principles. (Degree of Doctor of Philosophy PhD), The University of Salford, Salford, UK.

Amaratunga, D., \& Baldry, D. (2000). Assessment of facilities management performance in higher education properties. Facilities, 18(7/8), 293-301.

Bakhtiar, K. A., Li, Y. S. \& Misnan, S. H. (2008). A framework for a comparison study on the major methods in promoting sustainable construction practice. Jurnal Alam Bina, 12(3), 55-69.

Beheiry, S. M. A., Chong, W. K., \& Haas, C. T. (2006). Examining the business impact of owner commitment to sustainability. Journal of construction engineering and management, 132, 384.

Bertels, S., Papania, L., \& Papania, D. (2010). Embedding sustainability in organizational culture. A systematic review of the body of knowledge. London, Canada: Network for Business Sustainability.

Boyle, C. (2003). Sustainability assessment: Assessing the sustainability of business activities. Paper presented at the 10th International Conference of the Greening of Industry Network, Göteborg, Sweden.

Du Plessis, C. (2007). A strategic framework for sustainable construction in developing countries. Construction Management and Economics, 25(1), 67 - 76.

Dunphy, D., Griffiths, A., \& Benn, S. (2003). Organizational change for corporate sustainability: a guide for leaders and change agents of the future. London: Routledge.

Elle, M., Hoffman, B., Nielsen, S. B., \& Jensen, J. O. (2005). Sustainability in the existing building stock: the role of sustainable facilities management. Paper presented at The 2005 World Sustainable Building Conference: Action for Sustainability, Tokyo.

Environmental Protection Agency. (2013). Climate change science overview. Retrieved from the United States Environmental Protection Agency website: http://www.epa.gov/climatechange/science/overview.html;http://www.epa.gov/climatechange/science/future.html

Finch, E., \& Zhang, X. (2013). Facilities management Design and Management of Sustainable Built Environments (pp. 305-326): Springer.

fmedge. (2012). What is Facility Management? Retrieved 18 August 2012, 2012, from http://www.fmedge.com.au/index.php?option=com content\&view=article\&id=27\&ltemid=28

Guest, G., Bunce, A., \& Johnson, L. (2006). How Many Interviews are Enough? An Experiment with Data Saturation and Variability. Field methods, 18(1).

Hecht, A. D. (1999). The Triad of Sustainable Development: Promoting Sustainable Development in Developing Countries. The Journal of Environment Development, 8(2), 111-132. doi: 10.1177/107049659900800202

Hitchcock, D. E., \& Willard, M. L. (2006). The business guide to sustainability: practical strategies and tools for organizations. London, UK: Earthscan Ltd. 
Hodges, C. (2005). A facility manager's approach to sustainability. Journal of Facilities Management, 3(4), 312324.

Intergovernmental Panel on Climate Change. (2007). Climate Change 2007: Mitigation. Contribution of Working Group III to the Fourth Assessment Report of the Intergovernmental Panel on Climate Change. The United Kingdom and New York, NY, USA: Cambridge University Press, Cambridge.

Koukiasa, M. (2011). Sustainable facilities management within event venues. Worldwide Hospitality and Tourism Themes, 3(3), 217-228.

Langston, C., \& Lauge-Kristensen, R. (2012). Strategic management of built facilities. Hoboken: Taylor and Francis.

Lavy, S. (2008). Facility management practices in higher education buildings: A case study. Journal of Facilities Management, 6(4), 303-315.

Lee, S. Y., \& Kang, M. (2013). Innovation characteristics and intention to adopt sustainable facilities management practices. Ergonomics(ahead-of-print), 1-12.

Marlow, D. (2008). Sustainability-Based Asset Management Water for a Healthy Country Flagship Report: Water Services Association (WSA).

Mayton, J. H., III. (2007). Introducing Sustainable Facility. Sustainable Facility, 32(10), 6.

Metz, B., Davidson, O., Bosch, P., Dave, R., \& Meyer, L. (2007). Climate Change 2007 Mitigation: Contribution of Working Group III to the Fourth Assessment Report of the Intergovernmental Panel on Climate Change. Canada: Cambridge University Press New York, USA Retrieved from http://www.ipcc.ch/pdf/assessment-report/ar4/wg3/ar4wg3-frontmatter.pdf.

Moller, S., \& McCartney, D. (2007). Facilities management and maintenance and sustainable commercial buildings. Retrieved from Your Building : Profiting from Sustainability website: http://www.yourbuilding.org/Article/NewsDetail.aspx?p=83\&id=1603

Nejati, M., Shafaei, A., Salamzadeh, Y., \& Daraei, M. (2011). Corporate social responsibility and universities: A study of top 10 world universities' websites. African Journal of Business Management, 5(2), 440-447.

Nielsen, S. B., \& Galamba, K. R. (2010). Facilities Management - When Sustainable Development is Core Business. Paper presented at the European Facility Management Conference 2010, Madrid, Spain.

Nielsen, S. B., Jensen, P. A., \& Jensen, J. O. (2012). The Strategic Facilities Management Organisation in Housing: Implications for Sustainable Facilities Management. International Journal of Facility Management, 3(1).

Nielsen, S. B., Møller, J. S., Jäschke, S., \& Alexander, K. (2012). Realizing Sustainability in Facilities Management: a pilot study at the Technical University of Denmark. Paper presented at the $11^{\text {th }}$ EuroFM Research Symposium (EFMC 2012), Copenhagen.

Ogbeifun, E. (2011). Facilities Management in a Multi-Campus Setting: A Case Study of the University of the Witwatersrand. (Master of Science in Engineering M.Sc.), University of the Witwatersrand, Johannesburg. Retrieved from http://wiredspace.wits.ac.za/bitstream/handle/10539/10585/Edoghogho\%200gbeifun\%20Final.pdf

Opoku, A., \& Fortune, C. (2011). Leadership in Construction Organizations and the Promotion of Sustainable Practices. Paper presented at the Management and Innovation for a Sustainable Built Environment, Amsterdam, The Netherlands. 
Pathirage, C., Amaratunga, R., Baldry, D., \& Haigh, R. (2006). Key knowledge management variables for facilities management organisational effectiveness. Paper presented at the CIB W89 International Conference on Building Education and Research (BEAR), The Hong Kong Polytechnic University, Hong Kong.

Pathirage, C., Haigh, R., Amaratunga, D., \& Baldry, D. (2008). Knowledge management practices in facilities organisations: a case study. Journal of Facilities Management, 6(1), 5-22.

Petrini, M., \& Pozzebon, M. (2010). Integrating Sustainability into Business Practices: Learning from Brazilian Firms. Brazilian Administration Review, 7, 362-378.

Porter, T. B. (2008). Managerial applications of corporate social responsibility and systems thinking for achieving sustainability outcomes. Systems Research and Behavioral Science, 25(3), 397-411.

$\begin{array}{lllll}\text { Probst-Wallace, } & \text { D. What is Facility }\end{array}$ http://www.ifma.org.hk/download/what_is_facility_management.pdf

Puddy, J. R., Price, I., \& Smith, L. (2001). FM policies and standards as a knowledge management system. Facilities, 19(13/14), 504-515.

Reineck, M., Poltermann, J., May, M., \& Pelzeter, A. (2012). Measuring Corporate Sustainable Development in Facilities Management with Key Performance Indicators. OIDA International Journal of Sustainable Development. Robinson, J. (2004). Squaring the circle? Some thoughts on the idea of sustainable development. Ecological Economics, 48(4), 369-384.

Sarpin, N., \& Yang, J. (2012). The promotion of sustainability agenda for facilities management through developing knowledge capabilities. Paper presented at the Proceedings of APSEC 2012 \& ICCER2012, Surabaya, Indonesia.

Székely, F., \& Knirsch, M. (2005). Responsible Leadership and Corporate Social Responsibility: Metrics for Sustainable Performance. European Management Journal, 23(6), 628-647.

United Nations Environment Programme. (2009). Buildings and Climate Change: Summary for Decision-Makers: United Nations Environment Programme: Sustainable Buildings \& Climate Initiative.

United States Green Building Council. (2003). Building Momentum: National Trends and Prospects for Highperformance Green Buildings. Washington, DC: US Green Building Council.

Vanegas, J. A. (2003). Road map and principles for built environment sustainability. Environmental Science \& Technology, 37(23), 5363-5372. doi: 10.1021/es030523h

Vanier, D. J. (2001). Why Industry Needs Asset Management Tools. Journal of Computing in Civil Engineering, 15(1), 35.

Warren-Myers, G. (2013). Sustainable management of real estate: is it really sustainability? Journal of sustainable real estate, 4(1), 177-197.

Wiggins, J. M. (2010). History of Facilities Management Facilities Manager's Desk Reference (pp. 1-8). Hoboken, NJ, USA: Wiley-Blackwell.

Williams, D., \& Sutrisna, M. (2010). An evaluation of the role of facilities managers in managing sustainability and remedial actions in reducing $\mathrm{CO}_{2}$ emissions in the built environment. Paper presented at the RICS COBRA Conference, Dauphine University, Paris. 
Hasim, M.S., et.al./ Asian Journal of Behavioural Studies (AjBeS), 5(18), Jan/Apr 2020 (pp.51-67)

Wood, B. (2006). The role of existing buildings in the sustainability agenda. Facilities, 24(1/2), 61-67. doi: $10.1108 / 02632770610639206$

Wright, T. S. A., \& Wilton, H. (2012). Facilities management directors' conceptualizations of sustainability in higher education. Journal of Cleaner Production, 31, 118-125. doi: 10.1016/j.jclepro.2012.02.030

Yin, R. K. (1994). Case study research: Design and methods (2nd ed.). Thousand Oaks, CA: Sage Publishing. 